To cite this article: Clement C. Ukangwa, Evans C. Otuza \& Maria Ehioghae (2020) Influence of Information Sharing on Job Satisfaction of Librarians in Private Universities in SouthEast and South-West, Nigeria. Information Impact: Journal of Information and Knowledge Management, 11:4, 1-12, DOI: https://dx.doi.org/10.4314/iijikm.v11i4.1

To link to this article: https://dx.doi.org/10.4314/iijikm.v11i4.1

\title{
Influence of Information Sharing on Job Satisfaction of Librarians in Private Universities in South-East and South-West, Nigeria
}

\author{
${ }^{1}$ Clement Chinemerem Ukangwa \\ ${ }^{2}$ Evans Chima Otuza \\ ${ }^{1}$ Maria Ehioghae \\ ${ }^{1}$ Babcock University Library, Ilishan-Remo, Ogun State, Nigeria \\ ${ }^{2}$ Clifford University Library, Ihie, Abia State, Nigeria
}

\begin{abstract}
The stud investigated how information sharing affects job satisfaction of Librarians in Private Universities in South-East and South-West, Nigeria. The study adopted the survey research design. The population of the study consisted of one hundred and eighty-one (181) librarians from Private Universities in SouthEast and South-West, Nigeria. Total enumeration technique was employed for the study. A self-structured and validated questionnaire was used to collect data. The Cronbach's Alpha reliability coefficient for the variables ranged from .705 to .908 . A response rate of $90 \%$ was obtained. Analyses of data were carried out using descriptive statistics, Pearson Product Moment Correlation and multiple regression. Findings showed that the the individual effects of information sharing on job satisfaction were significant: information sharing $(\beta=.027 ; \mathrm{t}=2.179 ; \mathrm{p}<.05)$. Furthermore, the study revealed that information sharing had a significant positive relationship with job satisfaction $(r=.414$, $\mathrm{p}<.05)$. The study concluded that information sharing had significant effect on job satisfaction. The study therefore recommended that the library management should invest in infrastructural and manpower development of the library, as well as the overall welfare of librarians to enhance their job satisfaction. Furthermore, the library management should make provision for the use of high technology laboratories for information sharing.
\end{abstract}

Keywords Information sharing, Job satisfaction, Librarians, Private Universities

CONTACT Clement C. Ukangwa, Evans C. Otuza and Maria Ehioghae ukangwaclement@gmail.com Obafemi Babcock University Library, Ilishan-Remo,Ogun State, Nigeria and Clifford University Library, Ihie, Abia State, Nigeria. 2020 The Authors Published with License by Information Impact 


\section{Introduction}

The library is the knowledge center of the academic institution where people go to acquire knowledge. Libraries are managed by information professionals called librarians who equip it with textbooks, journals, almanacs, newspapers, films, and videos, magazines, and electronic resources to meet the information needs of users. Librarians' administrative, technical and advisory duties which range from the management of libraries which include planning and supervision of the day-to-day activities, the acquisition, processing, and organisation of information materials for easy retrieval, to ensuring that library users are brought in contact with needed information materials. To carry out their work effectively, it is expected that librarians have a sense of fulfillment in what they do which is referred to as job satisfaction.

Job satisfaction is a measure of how contented an individual is with his or her job, in other words, whether or not they like the job or individual aspects of the jobs such as the nature of work or supervision (Spector, 2011). A person may be satisfied with all or some aspects of his or her work hence some librarians may be satisfied with the intrinsic part of their jobs such as responsibility, achievement or the work itself while others may find satisfaction only in those things which are external or extrinsic in nature such as supervision, relationship with co-workers and pay. Job satisfaction of librarians is important to university libraries as it is one of the major indications of successful library. A librarian who cannot get a sufficient wage will be faced with the problem of maintaining his or her family's life and professional status. This brings about a feeling of dissatisfaction from the librarians. The problem could come from the social facilities such as (transportation services, and consumer cooperatives) which are not sufficient because of the economic conditions of the country they find themselves. When there is low wages, lack of status and social security, it affects motivational level of employee. Job satisfaction cannot be attained where there is absence of motivation. Job satisfaction of the librarian who has an important place in the information society will affect the quality of the service he/she renders in the academic library (Kikelomo, et al' 2017).

Job satisfaction is so important in that when it is not sufficient, it causes reduced organizational commitment. It is observed that when there is lack of job satisfaction among employees, the tendency to quit job and migrate into another becomes high. The movement could be from one profession to another or from one country to another that is considered a greener pasture. In such countries, people tend to migrate to better and consistently paying jobs. Satisfaction on a job might be motivated by the nature of the job, its pervasive social climate and extent to which workers peculiar needs are met. The need for job satisfaction among librarians is pointed out by Kaur (2006) who expressed the opinion that satisfied librarians are more likely to put in more efforts at their jobs than their less satisfied colleagues. Beyond, dealing with the technical aspects of their jobs which centre mostly around the acquisition and organisation of information resources, librarians also interact with users on a daily basis, either through the provision of advisory or instructional service which heightens the need for job satisfaction. Indeed, Mallaiah (2008) as cited in Anyaoku, Osuigwe, and Oguaka (2015) affirms that where a librarian is dissatisfied with his or her job, there is a tendency for the display of negative attitude towards library users.

Job satisfaction has been of tremendous concern to researchers worldwide. In Pakistan, Khan and Ahmed (2013) carried out a study on the job satisfaction of library professionals in public universities and arrived at the conclusion that they are slightly satisfied. In Nigeria, Onuoha, Samuel and Ojo (2014) examined the job satisfaction of library personnel in private universities in Ogun State and affirmed moderate positive level of job satisfaction among library employees while reporting stringent conditions for promotion, denied access to benefits and lack of job security as major constraints to job satisfaction. While it is vital for librarians to be satisfied with their job, it is also necessary to have a system of information sharing that would ensure adequate flow of information. 
The term information sharing in the information technology lexicon has a long history. Traditionally, information sharing has to do with the exchange of data one-to-one between a sender and the receiver. These information exchanges are implemented via dozens of open and proprietary protocols message and file formats. Information sharing refers to the disclosure, exchange or receipt of personal information by any method, e.g., transmission, provision of a copy, examination of the record, to/from anybody or person (Serban, Andreea, \& Luan, 2002). Information sharing is a special skill required of librarians due to the emerging advent of information communication technology (ICT) which requires the acquisition of new skills and new methods of doing things. There is, therefore, need for librarians working in university libraries to equip themselves with relevant tacit and explicit knowledge and share it in order to cope with the rapid changes occurring in libraries. Information sharing in the form of consulting and informal communication is a widely recognized phenomenon in information science literature. It implies that there exist significant predictors between information sharing among scholars in advancing knowledge sharing practices.

Fari and Ocholla (2015) among others found that the use of technological tools such as computer, information and data storage devices, mobile phones and internet facilities by academics is the strongest predictor of information sharing. Information sharing correlates positively with perceived individual effectives and project performance. Studies on scholarly information seeking have long since established that researchers in most fields prefer informal information sharing sources and channels over formal searches, as the use of informal sources saves time and energy. For instance, socially oriented information seeking is typical for senior social scientists having a long information seeking career and a great deal of social capital, and formally oriented searching is typical for junior researchers with shorter information seeking careers and less social capital. Previous literature on scholars' information seeking revealed that information sharing is as a method of information acquisition in academic environments as information encountering (Erdelez, 2011). These methods have rarely been taken as objects of analysis in their own right. Information sharing practices have usually been described with distinctions such as the use of person vs. documentary sources, formal vs. informal channels, and social vs. technical searching. These distinctions seem to be oriented towards explaining why scholars do not always use the document retrieval systems designed to assist them, describing aspects of scholars' information seeking that are important from the viewpoint of information professionals. The concept of information sharing is crucial to university libraries because no organization can succeed without the contribution of those within the system. If librarians do not share information among themselves, less skilled staff will not acquire the knowledge they need to better their performance also as people leave the organization due to retirement or death as the case may be, they leave with the knowledge acquired over the years in the course of their duties, thereby, leaving the ones coming behind with little or nothing to work with which may lead to job dissatisfaction. Current studies, Suliman and AlHosani (2014); Liao et al., (2004) affirmed a positive link between job satisfaction and information sharing. Considering the importance of information sharing in libraries, it is therefore necessary to study it, especially as it relates to the job satisfaction of librarians in private universities in South-East and South-West, Nigeria, which is the focus of this study.

\section{Statement of Problem}

The university library is the powerhouse of knowledge in most academic institutions as it is mainly responsible for providing information resources to meet the teaching and learning needs of the university environment. For the university library to run effective, librarians who are responsible for the day-to-day activities of libraries must be on ground. There is need for librarians to be fulfilled in their job and in turn, 
render effective services. Unfortunately, this is not the case as previous studies have suggested that there is an increasing trend of high turnover as a result of dissatisfaction among librarians in Nigerian universities. Even though information sharing has been associated with job satisfaction, some librarians still do not share information with their colleagues, and this negatively affects knowledge transfer, continuity and overall job satisfaction of librarians. It is in view of these identified problems that this study was conducted to analyze the specific contribution of information sharing to job satisfaction.

\section{Objective of the Study}

The general objective of the study is to find out the influence of information sharing on job satisfaction of private university librarians in South-East and South-West, Nigeria. The specific objectives are to:

1. ascertain the extent to which librarians are satisfied with their job in private universities in SouthEast and South-West, Nigeria;

2. identify the degree of information sharing practice of librarians in South-East and South-West, Nigeria;

3. find out the relationship between information sharing and job satisfaction of librarians in private universities in South-East and South-West, Nigeria;

4.

\section{Hypotheses}

The null hypothesis is tested at 0.05 level of significance:

$\mathrm{H}_{0}$ : There is no significant relationship between information sharing and librarian's job satisfaction in South-East and South-West, Nigeria.

\section{Methodology}

This study made use of survey research design since it is adequate due to its dependability in terms of anonymity of respondents which allows them to give reliable answers to questions. Therefore, the population was made up of one hundred and eighty-one (181) librarians. One hundred and fifty six (156) are from South-West, while twenty five (25) are from South-East. The study instrument was a self-structured questionnaire designed in line with the objectives of the study. The questionnaire was pre-tested 30 librarians in four private university libraries not included in the study population. The universities selected for the trial test are Igbinedion University, Wellspring University, Benson Idahosa University, and Western Delta University. These Universities were selected because they share the same characteristics with the actual universities for the study. The pre-test also enabled the researchers to correct ambiguous questions to ensure that the actual members of the study population would have a good understanding of the questions raised in the questionnaire. Considering the manageable population size, a total enumeration of all members of the population (181) was used for the study. Descriptive statistics such as frequency distribution, percentages, mean and standard deviation were used to analyze the research questions, while the hypothesis was tested using Pearson Product Moment Correlation. Out of 181 copies of the questionnaire distributed and retrieved, 176 were found useable. 
Table 1: Private Universities in South-West Nigeria: location, year established and

population of Librarians

\begin{tabular}{|c|c|c|c|c|}
\hline $\mathbf{S} / \mathbf{N}$ & Name of Private Universities & Location & Year & No of Librarians \\
\hline 1 & Adeleke University & Ede, Osun State & 2011 & 5 \\
\hline 2 & Afe Babalola University & Ado-Ekiti, Ekiti State & 2009 & 6 \\
\hline 3 & Ajayi Crowther University & Oyo & 2005 & 5 \\
\hline 4 & Al-Hikmah University & Ilorin & 2005 & 2 \\
\hline 5 & Augustine University & Ilara, Lagos State & 2015 & 5 \\
\hline 6 & Babcock University & Ilishan-Remo & 1991 & 16 \\
\hline 7 & Bells University of Technology & Ota, Ogun State & 2005 & 9 \\
\hline 8 & Bowen University & Iwo & 2001 & 9 \\
\hline 9 & Caleb University & Lagos & 2007 & 7 \\
\hline 10 & CETEP City University & Lagos & 2005 & 1 \\
\hline 11 & Chrisland University & Owode, Ogun State & 2015 & 2 \\
\hline 12 & Christopher University & Mowe, Ogun State & 2015 & 1 \\
\hline 13 & Covenant University & Ota & 2002 & 21 \\
\hline 14 & Crawford University & Igbesa, Ogun State & 2005 & 4 \\
\hline 15 & Crescent University & Abeokuta & 2005 & 5 \\
\hline 16 & Elizade University & Ilara- Mokin, Ondo State & 2012 & 3 \\
\hline 17 & Fountain University & Osogbo & 2007 & 4 \\
\hline 18 & Hallmark University & Ijebu Itele, Ogun State & 2015 & 2 \\
\hline 19 & Joseph Ayo Babalola University & Ikeji-Arakeji Osun State & 2006 & 7 \\
\hline 20 & Landmark University & Omu-Aran, Kwara State & 2011 & 1 \\
\hline 21 & Lead City University & Ibadan, Oyo State & 2005 & 6 \\
\hline 22 & McPherson University & $\begin{array}{l}\text { Seriki Sotayo, Ajebo, Ogun } \\
\text { State }\end{array}$ & 2012 & 3 \\
\hline 23 & Mountain Top University & Ogun State & 2015 & 1 \\
\hline 24 & Oduduwa University & Ipetumodu, Osun State & 2009 & 7 \\
\hline 25 & Pan-Atlantic University & Lagos & 2002 & 6 \\
\hline 26 & Redeemers University & Mowe, Ogun State & 2005 & 7 \\
\hline 27 & Southwestern University & Okun Owa, Ogun State & 2012 & 2 \\
\hline 28 & Achievers University & Owo, Ondo State & 2007 & 5 \\
\hline 29 & $\begin{array}{l}\text { Wesley University of Science \& } \\
\text { Technology }\end{array}$ & Ondo & 2007 & 4 \\
\hline & \multicolumn{2}{|l|}{ Total } & & 156 \\
\hline
\end{tabular}

Table 2: Private Universities in South-East Nigeria: location, year established and population of Librarians

\begin{tabular}{|l|l|l|l|l|}
\hline S/N & Name of Private Universities & Location & Ownership & No of Librarians \\
\hline 1 & Evangel University, Akaeze & Ebonyi & Private & 02 \\
\hline 2 & $\begin{array}{l}\text { Godfrey Okoye University, Ugwuomu- } \\
\text { Nike- Enugu State }\end{array}$ & Enugu & Private & 02 \\
\hline 3 & Gregory University, Uturu & Abia & Private & 02 \\
\hline 4 & Madonna University, Okija & Anambra & Private & 10 \\
\hline 5 & Paul University, Awka, Anambra State & Anambra & Private & 02 \\
\hline 6 & Renaissance University, Enugu & Enugu & Private & 03 \\
\hline 7 & Tansian University, Umunya & Anambra & Private & 02 \\
\hline 8 & Caritas University & Enugu & Private & 02 \\
\hline & Total & & $\mathbf{2 5}$ \\
\hline
\end{tabular}




\section{Presentation of Demographic Data of the Respondents}

The demographic variables of the respondents were collated, analyzed and presented with the use of percentage point and frequency distribution. The result was presented in table 3

Table 3: Demographic Characteristics of Respondents

\begin{tabular}{|c|c|c|c|}
\hline Characteristics & Categories & Frequency & Percentage \% \\
\hline \multirow[t]{7}{*}{ Age } & Below 25 & 6 & 3.4 \\
\hline & $26-30$ & 79 & 44.9 \\
\hline & $31-35$ & 43 & 24.4 \\
\hline & $36-40$ & 36 & 20.5 \\
\hline & $41-45$ & 8 & 4.5 \\
\hline & 46 above & 4 & 2.3 \\
\hline & Total & 176 & 100 \\
\hline \multirow[t]{3}{*}{ Gender } & Male & 98 & 55.7 \\
\hline & Female & 78 & 44.3 \\
\hline & Total & 176 & 100 \\
\hline \multirow[t]{3}{*}{ Religion } & Christianity & 144 & 81.8 \\
\hline & Islam & 32 & 18.2 \\
\hline & Total & 176 & 100 \\
\hline \multirow[t]{5}{*}{ Marital Status } & Married & 143 & 81.3 \\
\hline & Single & 21 & 11.9 \\
\hline & Divorced & 4 & 2.3 \\
\hline & Separated & 8 & 4.5 \\
\hline & Total & 176 & 100 \\
\hline \multirow[t]{6}{*}{ Academic Qualification } & OND & 8 & 4.5 \\
\hline & HND & 27 & 15.3 \\
\hline & B. Sc & 31 & 17.6 \\
\hline & M. Sc & 81 & 46.0 \\
\hline & Ph.D. & 29 & 16.5 \\
\hline & Total & 176 & 100 \\
\hline \multirow[t]{5}{*}{ Rank } & Librarian II & 72 & 40.9 \\
\hline & Librarian I & 53 & 30.1 \\
\hline & Library Officer & 17 & 9.7 \\
\hline & Assistant Librarian & 34 & 19.3 \\
\hline & Total & 176 & 100 \\
\hline \multirow[t]{5}{*}{ Years of work Experience } & Below 5 years & 70 & 39.8 \\
\hline & $6-10$ years & 82 & 46.6 \\
\hline & $11-15$ years & 20 & 11.4 \\
\hline & 16 years and above & 4 & 2.3 \\
\hline & Total & 176 & 100 \\
\hline \multirow[t]{9}{*}{ Unit/Department in the library } & Circulation & 10 & 5.7 \\
\hline & Acquisition & 37 & 21.0 \\
\hline & Technical Services & 21 & 11.9 \\
\hline & Reference Section & 8 & 4.5 \\
\hline & Serials Section & 20 & 11.4 \\
\hline & $\begin{array}{l}\text { IT/Automation/Digital } \\
\text { section }\end{array}$ & 45 & 25.6 \\
\hline & Readers Services & 23 & 13.1 \\
\hline & $\begin{array}{l}\text { Collection } \\
\text { development }\end{array}$ & 12 & 6.8 \\
\hline & Total & 176 & 100 \\
\hline
\end{tabular}


Table 3 result shows that majority of the respondents (44.9\%) were between ages 26-30years. Ages 46 are the lowest in response frequency (2.3\%). This implies that most of the librarians were more of ages 26$30 y e a r s$ range at the time of data collection. Most of the respondents $(55.7 \%)$ were male as against female (44.3\%), and this implies that more male were librarians in most of the libraries examined under study. The distribution of the respondents by religion showed that majority (81.8\%) were Christians, the reason could be that most of the higher institutions were Christian owned or more of the respondents were Christians. Majority of the respondents (81.3\%) were married, while $2.3 \%$ were divorced. Furthermore, most of respondents $(46.0 \%)$ have M.Sc as their highest educational qualification while the least qualification was OND (4.5\%). A large number of the respondents (40.9\%) were Librarian II in ranking while $9.7 \%$ were library officers and the least in response rate. Most of the librarians (46.6\%) have worked for 6-10years as librarians, while 16years working experience ranked the lowest (2.3\%). Furthermore, majority (11.4\%) were from Convenant University while the smallest group (.6\%) of librarians was from Landmark University. Most (25.6\%) were IT/Automation/Digital librarians, while the lowest number of librarians (4.5\%) was found to come from the reference unit. This implies that most of the respondents were from IT/Automation/Digital section and the least from reference section as at when the data was collected.

Research Question one: To what extent are librarians satisfied with their jobs in private universities in South-East and South-West, Nigeria?

Table 4: Job Satisfaction of Librarians

\begin{tabular}{|c|c|c|c|c|c|c|c|c|}
\hline $\mathbf{S} / \mathbf{N}$ & Job Satisfaction of librarians? & $\begin{array}{l}\text { VHS } \\
(\%)\end{array}$ & HS (\%) & MS (\%) & $\mathbf{S}(\%)$ & NS (\%) & $\overline{\mathrm{X}}$ & SD \\
\hline 1 & $\begin{array}{l}\text { I am satisfied with the existing } \\
\text { relationship between departments } \\
\text { and colleagues in my library }\end{array}$ & - & $\begin{array}{l}8 \\
(4.5)\end{array}$ & $\begin{array}{l}14 \\
(8.0)\end{array}$ & $\begin{array}{l}108 \\
(61.4)\end{array}$ & $\begin{array}{l}46 \\
(26.1)\end{array}$ & 4.09 & .719 \\
\hline 2 & $\begin{array}{l}\text { I am satisfied when my future and job } \\
\text { security are not guaranteed in the } \\
\text { present job }\end{array}$ & $\begin{array}{l}2 \\
(1.1)\end{array}$ & $\begin{array}{l}12 \\
(6.8)\end{array}$ & $\begin{array}{l}37 \\
(21.0)\end{array}$ & $\begin{array}{l}41 \\
(23.3)\end{array}$ & $\begin{array}{l}84 \\
(47.7)\end{array}$ & 3.85 & .895 \\
\hline 3 & $\begin{array}{l}\text { I am satisfied when my experience is } \\
\text { well appreciated and rewarded }\end{array}$ & $\begin{array}{l}10 \\
(5.7)\end{array}$ & $\begin{array}{l}21 \\
(11.9)\end{array}$ & $\begin{array}{l}19 \\
(10.8)\end{array}$ & $\begin{array}{l}79 \\
(44.9)\end{array}$ & $\begin{array}{l}47 \\
(26.7)\end{array}$ & 3.75 & 1.144 \\
\hline 4 & $\begin{array}{l}\text { I am satisfied with healthy, clean, } \\
\text { conducive and safe physical working } \\
\text { environment shows }\end{array}$ & $\begin{array}{l}13 \\
(7.4)\end{array}$ & $\begin{array}{l}11 \\
(6.3)\end{array}$ & $\begin{array}{l}51 \\
(29.0)\end{array}$ & $\begin{array}{l}50 \\
(28.4)\end{array}$ & $\begin{array}{l}51 \\
(29.0)\end{array}$ & 3.65 & 1.176 \\
\hline 5 & $\begin{array}{l}\text { I am satisfied when I am recognized } \\
\text { for better performance }\end{array}$ & $\begin{array}{ll}7 \\
(4.0) \\
\end{array}$ & $\begin{array}{l}38 \\
(21.6)\end{array}$ & $\begin{array}{l}22 \\
(12.5)\end{array}$ & $\begin{array}{l}56 \\
(31.8) \\
\end{array}$ & $\begin{array}{l}53 \\
(30.1) \\
\end{array}$ & 3.62 & 1.231 \\
\hline 6 & $\begin{array}{l}\text { I am satisfied after I make use of new } \\
\text { devices for growth }\end{array}$ & $\begin{array}{l}7 \\
(4.0)\end{array}$ & $\begin{array}{l}20 \\
(11.4)\end{array}$ & $\begin{array}{l}39 \\
(22.2)\end{array}$ & $\begin{array}{l}83 \\
(47.2)\end{array}$ & $\begin{array}{l}27 \\
(15.3)\end{array}$ & 3.59 & 1.011 \\
\hline 7 & $\begin{array}{l}\text { I am satisfied when best subordinates } \\
\text { are recognized }\end{array}$ & - & $\begin{array}{l}44 \\
(25.0)\end{array}$ & $\begin{array}{l}24 \\
(13.6)\end{array}$ & $\begin{array}{l}74 \\
(42.0)\end{array}$ & $\begin{array}{l}34 \\
(19.3)\end{array}$ & 3.56 & 1.068 \\
\hline 8 & $\begin{array}{l}\text { I am satisfied when I participate in } \\
\text { training and development }\end{array}$ & - & $\begin{array}{l}41 \\
(23.3)\end{array}$ & $\begin{array}{l}28 \\
(15.9)\end{array}$ & $\begin{array}{l}76 \\
(43.2)\end{array}$ & $\begin{array}{l}31 \\
(17.6)\end{array}$ & 3.55 & 1.035 \\
\hline 9 & $\begin{array}{l}\text { I am satisfied when I have a cordial } \\
\text { relationship with other librarians }\end{array}$ & $\begin{array}{l}9 \\
(5.1)\end{array}$ & $\begin{array}{l}44 \\
(25.0) \\
\end{array}$ & $\begin{array}{l}17 \\
(9.7)\end{array}$ & $\begin{array}{l}61 \\
(34.7)\end{array}$ & $\begin{array}{l}45 \\
(25.6)\end{array}$ & 3.51 & 1.256 \\
\hline 10 & I am satisfied with my salary & $\begin{array}{l}3 \\
(1.7)\end{array}$ & $\begin{array}{l}39 \\
(22.2)\end{array}$ & $\begin{array}{l}38 \\
(21.6)\end{array}$ & $\begin{array}{l}68 \\
(38.6)\end{array}$ & $\begin{array}{l}28 \\
(15.9)\end{array}$ & 3.45 & 1.057 \\
\hline 11 & I am satisfied with my library building & $\begin{array}{l}4 \\
(2.3) \\
\end{array}$ & $\begin{array}{l}35 \\
(19.9) \\
\end{array}$ & $\begin{array}{l}54 \\
(30.7) \\
\end{array}$ & $\begin{array}{l}56 \\
(31.8) \\
\end{array}$ & $\begin{array}{l}27 \\
(15.3)\end{array}$ & 3.38 & 1.041 \\
\hline 12 & $\begin{array}{l}\text { I am satisfied when my organization } \\
\text { permits and highly values the } \\
\text { research of academic librarians }\end{array}$ & - & $\begin{array}{l}52 \\
(29.5)\end{array}$ & $\begin{array}{l}33 \\
(18.8)\end{array}$ & $\begin{array}{l}70 \\
(39.8)\end{array}$ & $\begin{array}{l}21 \\
(11.9)\end{array}$ & 3.34 & 1.030 \\
\hline 13 & $\begin{array}{l}\text { I am satisfied with the library } \\
\text { furniture's lightening and painting }\end{array}$ & $\begin{array}{ll}7 \\
(4.0)\end{array}$ & $\begin{array}{l}39 \\
(22.2)\end{array}$ & $\begin{array}{l}48 \\
(27.3)\end{array}$ & $\begin{array}{l}53 \\
(30.1)\end{array}$ & $\begin{array}{l}29 \\
(16.5)\end{array}$ & 3.33 & 1.113 \\
\hline
\end{tabular}




\begin{tabular}{|c|c|c|c|c|c|c|c|c|}
\hline & shows & & & & & & & \\
\hline 14 & $\begin{array}{l}\text { I am satisfied with the way my effort } \\
\text { is highly recognized and rewarded }\end{array}$ & $\begin{array}{l}6 \\
(3.4)\end{array}$ & $\begin{array}{l}61 \\
(34.7)\end{array}$ & $\begin{array}{l}25 \\
(14.2)\end{array}$ & $\begin{array}{l}51 \\
(29.0)\end{array}$ & $\begin{array}{l}33 \\
(18.8)\end{array}$ & 3.25 & 1.212 \\
\hline 15 & $\begin{array}{l}\text { I am satisfied with the level of } \\
\text { educational technology in my library }\end{array}$ & $\begin{array}{l}7 \\
(4.0)\end{array}$ & $\begin{array}{l}45 \\
(25.6)\end{array}$ & $\begin{array}{l}30 \\
(17.0)\end{array}$ & $\begin{array}{l}40 \\
(22.7)\end{array}$ & $\begin{array}{l}54 \\
(30.7)\end{array}$ & 3.23 & 1.130 \\
\hline 16 & $\begin{array}{l}\text { I am satisfied when it comes to } \\
\text { receiving both financial and non- } \\
\text { financial reward at workplace }\end{array}$ & - & $\begin{array}{l}65 \\
(36.9)\end{array}$ & $\begin{array}{l}35 \\
(19.9)\end{array}$ & $\begin{array}{l}61 \\
(34.7)\end{array}$ & $\begin{array}{l}15 \\
(8.5)\end{array}$ & 3.15 & 1.020 \\
\hline 17 & $\begin{array}{l}\text { My experience with timely salary } \\
\text { payment is satisfactory }\end{array}$ & $\begin{array}{l}25 \\
(14.2)\end{array}$ & $\begin{array}{l}62 \\
(35.2)\end{array}$ & $\begin{array}{l}23 \\
(13.1)\end{array}$ & $\begin{array}{l}55 \\
(31.3)\end{array}$ & $\begin{array}{l}11 \\
(6.3)\end{array}$ & 2.80 & 1.205 \\
\hline & Total & & & & & & 3.5 & \\
\hline
\end{tabular}

Key: Very Highly Satisfied (VHS), Highly Satisfied (HS), Moderately Satisfied (MS), Satisfied (S), Not Satisfied (NS)

Results in Table 4.3 show a high level of librarians job satisfaction with an average mean score $(\overline{\mathbf{X}}=3.5)$ on the scale of 5. Specifically, the satisfaction indicated by the respondents came from relationship between departments and colleagues within the library $(\overline{\mathrm{X}}=4.09, \mathrm{SD}=.719)$, when their future and job security is guaranteed in the present job $(\overline{\mathrm{X}}=3.85, \mathrm{SD}=.895)$, when their experience on the job is well appreciated and rewarded $(\overline{\mathrm{X}}=3.75, \mathrm{SD}=1.144)$, when there is healthy, clean, conducive and safe physical working environment $(\overline{\mathrm{X}}=3.65, \mathrm{SD}=1.176)$, when they are recognized for better performance $(\overline{\mathrm{X}}=3.62, \mathrm{SD}=$ $1.231)$, when they make use of new devices for growth $(\overline{\mathrm{X}}=3.59, \mathrm{SD}=1.011)$, when best subordinates are recognized $(\overline{\mathrm{X}}=3.56, \mathrm{SD}=1.068)$, when they participate in training and development $(\overline{\mathrm{X}}=3.55, \mathrm{SD}=$ 1.035), when they have cordial relationship with other librarians; meanwhile $25.6 \%$ are not satisfied; but on the average $(\overline{\mathrm{X}}=3.51, \mathrm{SD}=1.256)$ they are satisfied with their salary $(\overline{\mathrm{X}}=3.45, \mathrm{SD}=1.057)$, with library building $(\overline{\mathrm{X}}=3.38, \mathrm{SD}=1.041)$, when their organizations permit and highly value the research of librarians ( $\overline{\mathbf{X}}=3.34, \mathrm{SD}=1.030)$, and libraries' furniture, lighting and painting shows $(\overline{\mathrm{X}}=3.33, \mathrm{SD}=1.113)$. Other area of satisfaction include: high recognition and reward of efforts $(\bar{X}=3.25, \mathrm{SD}=1.212)$, educational technology in the libraries $(\overline{\mathrm{X}}=3.23, \mathrm{SD}=1.130)$, financial and non financial reward at workplace $(\overline{\mathrm{X}}=$ $3.15, \mathrm{SD}=1.020)$, and lastly, timely salary payment experience $(\overline{\mathrm{X}}=2.80, \mathrm{SD}=1.205)$.

Research Question two: What are the information sharing practices of librarians in private universities in South-East and South-West, Nigeria?

Table 5: information sharing practices of librarians

\begin{tabular}{|c|c|c|c|c|c|c|c|c|}
\hline $\mathbf{S} / \mathbf{N}$ & Statements & $\begin{array}{l}\text { SA } \\
(\%)\end{array}$ & $\begin{array}{l}A \\
(\%)\end{array}$ & $\begin{array}{l}\text { D } \\
(\%)\end{array}$ & SD (\%) & $\mathbf{U}(\%)$ & $\overline{\mathbf{X}}$ & SD \\
\hline 1 & $\begin{array}{l}\text { I often share information during face-to- } \\
\text { face communication }\end{array}$ & $\begin{array}{l}109 \\
(61.9)\end{array}$ & $\begin{array}{l}62 \\
(35.2)\end{array}$ & $\begin{array}{l}5 \\
(2.8)\end{array}$ & - & - & 4.32 & .527 \\
\hline 2 & $\begin{array}{l}\text { I share information with my team through } \\
\text { presentation }\end{array}$ & $\begin{array}{l}121 \\
(68.8)\end{array}$ & $\begin{array}{l}46 \\
(26.1)\end{array}$ & $\begin{array}{ll}9 \\
(5.1)\end{array}$ & - & - & 4.21 & .519 \\
\hline 3 & $\begin{array}{l}\text { Information is shared within departments } \\
\text { through documentation }\end{array}$ & $\begin{array}{l}141 \\
(80.1)\end{array}$ & $\begin{array}{l}19 \\
(10.8)\end{array}$ & $\begin{array}{l}16 \\
(9.1)\end{array}$ & - & - & 4.02 & .447 \\
\hline 4 & $\begin{array}{l}\text { I get my team involved in sharing } \\
\text { information during brainstorming section }\end{array}$ & $\begin{array}{l}86 \\
(48.9)\end{array}$ & $\begin{array}{l}47 \\
(26.7)\end{array}$ & $\begin{array}{l}43 \\
(24.4)\end{array}$ & - & - & 4.02 & .717 \\
\hline 5 & I share information during discussion time & $\begin{array}{l}106 \\
(60.2)\end{array}$ & $\begin{array}{ll}36 \\
(20.5)\end{array}$ & $\begin{array}{l}12 \\
(6.8) \\
\end{array}$ & $\begin{array}{l}22 \\
(12.5)\end{array}$ & - & 3.89 & .874 \\
\hline 6 & $\begin{array}{l}\text { Training and development session is } \\
\text { another avenue used for sharing } \\
\text { information }\end{array}$ & $\begin{array}{l}96 \\
(54.5)\end{array}$ & $\begin{array}{l}35 \\
(19.9)\end{array}$ & $\begin{array}{l}21 \\
(11.9)\end{array}$ & $\begin{array}{l}2 \\
(1.1)\end{array}$ & $\begin{array}{l}22 \\
(12.5)\end{array}$ & 3.80 & .940 \\
\hline 7 & $\begin{array}{l}\text { Departmental meeting is another avenue I } \\
\text { use to share information }\end{array}$ & $\begin{array}{l}89 \\
(50.6)\end{array}$ & $\begin{array}{l}40 \\
(22.7)\end{array}$ & $\begin{array}{l}27 \\
(15.3)\end{array}$ & $\begin{array}{l}20 \\
(11.4)\end{array}$ & - & 3.85 & .904 \\
\hline 8 & Informal discussion is used for sharing & 50 & 109 & & 4 & 13 & 3.74 & .621 \\
\hline
\end{tabular}




\begin{tabular}{|c|c|c|c|c|c|c|c|c|}
\hline & information & $(28.4)$ & $(61.9)$ & & $\begin{array}{l}(2.3) \\
\end{array}$ & $\begin{array}{l}(7.4) \\
\end{array}$ & & \\
\hline 9 & $\begin{array}{l}\text { My supervisor organizes various } \\
\text { competitive programmes to enable efficient } \\
\text { information sharing across departments }\end{array}$ & $\begin{array}{l}11 \\
(6.3)\end{array}$ & $\begin{array}{l}6 \\
(3.4)\end{array}$ & $\begin{array}{l}53 \\
(30.1)\end{array}$ & $\begin{array}{l}67 \\
(38.1)\end{array}$ & $\begin{array}{l}39 \\
(22.2)\end{array}$ & 3.66 & 1.056 \\
\hline 10 & $\begin{array}{l}\text { My team makes use of high technology } \\
\text { laboratories for sharing information }\end{array}$ & $\begin{array}{l}2 \\
(1.1)\end{array}$ & $\begin{array}{l}34 \\
(19.3)\end{array}$ & $\begin{array}{l}20 \\
(11.4)\end{array}$ & $\begin{array}{l}90 \\
(51.1)\end{array}$ & $\begin{array}{l}30 \\
(17.0)\end{array}$ & 3.64 & 1.016 \\
\hline & \multicolumn{6}{|l|}{ Total } & 3.9 & \\
\hline
\end{tabular}

Key: Strongly Agree (SA), Agree (A), Disagree (D), Strongly Disagree (SD), Undecided (U)

Table 5 reveals that librarians are satisfied with their information sharing practices with an average $(\overline{\mathbf{X}}=$ 3.9) on the scale of 5. The Table shows that librarians often share information during face-to-face communication $(\overline{\mathrm{X}}=4.32, \mathrm{SD}=.527)$, share information with their team through presentation $(\overline{\mathrm{X}}=4.21$, $\mathrm{SD}=.519)$, share information within department through documentation $(\overline{\mathrm{X}}=4.02, \mathrm{SD}=.447)$, share information during brainstorming section $(\overline{\mathrm{X}}=4.02, \mathrm{SD}=.717)$, share information during discussion time $(\overline{\mathbf{X}}=3.89, \mathrm{SD}=.874)$, share information during training and development session $(\overline{\mathbf{X}}=3.80, \mathrm{SD}=.940)$, share information during departmental meetings $(\overline{\mathrm{X}}=3.85, \mathrm{SD}=.904)$, and during informal discussion $(\overline{\mathrm{X}}$ $=3.74, \mathrm{SD}=.621)$. However, disagreement with the following items: their Supervisor organizes various competitive programmes to enable efficient information sharing across departments $(\overline{\mathrm{X}}=3.66, \mathrm{SD}=1.056)$, and that their team makes use of high technology laboratories for sharing information $(\overline{\mathrm{X}}=3.64, \mathrm{SD}=$ 1.016).

\section{Test of Hypotheses}

$\mathbf{H}_{0}$ : There is no significant relationship between information sharing and librarian's job satisfaction in South-East and South-West, Nigeria.

Table 6: Result of Pearson Product Moment Correlation (PPMC) of IS and JS

\begin{tabular}{|c|c|c|c|c|c|c|}
\hline Variable & Mean & Std. Dev. & $\mathbf{N}$ & $\mathbf{R}$ & $\mathbf{P}$ & Remark \\
\hline Information Sharing Practice & 39.15 & 4.865 & \multirow{2}{*}{176} & \multirow{2}{*}{414} & \multirow{2}{*}{.000} & \multirow{2}{*}{ Sig. } \\
\hline Job Satisfaction of Librarians & 62.50 & 12.894 & & & & \\
\hline
\end{tabular}

Table 7 shows that there is positive and statistically significant correlation between information sharing behaviour and job satisfaction of librarians $(r=0.414, p<0.05)$ in South-East and South-West, Nigeria. The null hypothesis is therefore rejected. This indicates that when there is improvement in information sharing, there will be improvement in job satisfaction of librarians.

\section{Discussion of Findings}

In relation to librarians' job satisfaction in private universities in South-East and South-West, Nigeria, it was found that most of the librarians were satisfied with their job and they enjoyed cordial relationship between colleagues and sections in the library. These findings corroborated with the study of Burd (2003) who examined Work Values of Academic Librarians: Exploring the Relationships between Values, Job Satisfaction, Commitment and Intent to leave in the United States of America. He found that when librarians find themselves in an organization where participatory management is cultivated, open communication is allowed and relationships are built on honesty and trust, their tendency towards job satisfaction is guaranteed which makes them more committed to their job and less likely to leave. Also, in line with this result is the finding of Hazarika (2012) that lack of job satisfaction hampers the efficiency of the organization and people 
in it. Also, Adio and Popoola (2010) in their study on the relationship between job satisfaction and career commitment of librarians in Nigerian federal University libraries found that the dissatisfaction of the librarians is attributed to insufficient funding, lack of promotion, salary, recognition, and poor work condition. Abigail and Oluwatobi (2015) also affirm that poor supervisory support practice and harsh institutional policies present in organizations could bring about dissatisfaction among employees.

With regard to information sharing practice of librarians in private universities in South-East and SouthWest, Nigeria, the finding shows that the most employed information sharing practices of librarians were face-to-face communication, departmental meeting. Training and development session is another avenue used for sharing information, and discussion time. Binz-Scharf (2003) had earlier found that there were different means which employees can employ to share information within the organization such as meetings, telephone conversations, and document exchanges.

Findings also showed that the hypotheses which states that there is no statistically significant correlation between information sharing practices and job satisfaction of librarians in South-East and SouthWest, Nigeria was rejected as it was revealed that there is a positive and statistically significant correlation between them. The indication of this is that when there is improvement in information sharing practices such as face-to-face communication, presentation, documentation, brain storming sections, discussions, training and development sections, departmental meetings, informal discussions, competitive programmes, and use of high technology laboratories, there will be improvement in job satisfaction of librarians. If librarians do not share information among themselves, less skilled staff will not acquire the knowledge they need to better their performance also as people leave the organization due to retirement or death as the case may be, they leave with the knowledge acquired over the years in the course of their duties, thereby, leaving the ones coming behind with little or nothing to work with which may lead to job dissatisfaction. This is in line with the findings of Onifade (2015) in a study on knowledge sharing which revealed that Nigerian librarians in federal universities have a positive perception on knowledge sharing. Studies like those of Suliman and AlHosani (2014); Liao et al., (2004) also affirmed a positive link between job satisfaction and information sharing.

\section{Conclusion}

Information sharing significantly contributes towards the Job Satisfaction of Librarians in Private Universities in South-East and South-West Nigeria. The working culture most supported were trust and free information sharing among colleagues and management staff. From this study, it was found that most of the librarians were satisfied with the existing relationship between departments and their colleagues in the library, and on the other hand Librarians were dissatisfied with the fact that there is no job security in their present job, and very dissatisfied with the level of educational technology in the library. The study found that the most information sharing practices of librarians is face-to-face communication, and presentation, while the average practice of information sharing is during discussion time. Others were of the opinion that they share information during training and development session, while the least practice was the use of high technology laboratories to share information within the library. Test of hypothesis shows that there is a positive and statistically significant correlation between information sharing behaviour and job satisfaction of librarians $(r=0.414, \mathrm{p}<0.05)$ in South-East and South-West, Nigeria. 


\section{Recommendations}

Based on the identified challenges in the course of the study, the researcher therefore, made the following recommendations:

1. In view of lack of job security as a dissatisfactory factor experienced by librarians, the library management should increase the satisfaction level of librarians on the job by guarantying librarians of a better future and make provisions for their job security as soon as they meet certain criteria consistently over time.

2. The library management authority should make provision for the use of high technology laboratories for information sharing in and outside the library.

3. The management of library should make information sharing competitive by organizing various competitive programmes to enable efficient information sharing across departments of the library.

4. The management should create more time and energy towards advancing the facilities, structure and manpower of the library and the well-being of its workers to enhance satisfaction and encourage higher output.

\section{References}

Abigail, A. I. \& Oluwatobi, O. I. (2015). Job satisfaction and organizational commitment among library personel in selected libraries in Ogun State, Nigeria. Information and Knowledge Management, 5 (10), 20-30

Adio, G., \& Popoola, S. O. (2010). Job satisfaction and career commitment of librarians in federal university libraries in Nigeria. Library Review, 59(3): 175-184.

Anyaoku, E. N.; Osuigwe, N. E. \& Oguaka, C. N. (2015).Technology and Job Satisfaction in Academic Libraries: Role of Leadership Style and Librarians' Attitude International Journal of Library 4(4): $73-80$

Binz-Scharf, M.C. (2003). Exploration and Exploitation: Toward a Theory of Knowledge Sharing in Digital Government Projects, Dissertation.

Burd, B. (2003). Work Values of Academic Librarians: Exploring the Relationships between Values, Job Satisfaction, Commitment and Intent to Leave. ACRL Eleventh National Conference, April 10-13, Charlotte, North Carolina.

Erdelez, S. (2011). Information encountering: a conceptual framework for accidental information discovery. In: P. Vakkari, R. Savolainen, and B. Dervin, eds. Information seeking in context: proceedings of an international conference on research in information needs, seeking and use in different contexts, 14-16 August, Tampere, Finland. London: Taylor Graham, 412-421.7. TWIDALE

Fari, S. A., \& Ocholla, D. (2015). Comparative assessment of information and knowledge sharing among academics in selected universities in Nigeria and South Africa. South African Journal of Libraries And Information Science, Vol. 81, No 1

Hazarika, N. (2012). A survey of Job satisfaction among university professional in Asian Indcein 
journal of Library and Information science. Retrieved June 28, 2017 from: http://www.chaiduarcollege.org/doc/Mikhi/\%20Hazarika.pdf

Kaur, R., (2006). “Librarians' Job Satisfaction: Nature, Determinants and Theories.” International Library Association Bulletin. 42.4: 5-12.

Khan, A. \& Ahmed, H. (2013). Job satisfaction in the Universities of Khyber Patkhtunkhwa, Pakistan: A survey; Library Philosophy and Practice (e-journal) Paper 906 http://digitalcommons.unl.edu/libphilprac/906

Kikelomo, A., Wahab, A., \& Godwin, O. (2017). Job Satisfaction And Self-Efficacy as Determinants of Job Performance of Library Personnes in Selected University Libraries in South-West Nigeria. Library Philosophy And Practice (E-journal)

Liao, S., Chang, J., Cheng, S. \&, Kuo, C. (2004). Employee relationship and knowledge sharing: a case study of a Taiwanese finance and securities firm, Knowledge Management Research \& Practice 2 (1):24-34.

Mallaiah, T.Y. and Yadapadithaya, P.S., (2009). Intrinsic Motivation of Librarians in University Libraries in Karnataka DESIDOC Journal of Library \& Information Technology, Vol. 29, No. 3, May 2009, pp. 36-42 @ 2009, DESIDOC.

Onifade, F. N. (2015). Knowledge sharing among librarians in Federal University Libraries in Nigeria. Information and Knowledge Management, 5 (2). Retrieved from: iiste.org/journal/index.php/IKM/article/view/20587

Onuoha, U. D., Samuel, T. D. \& Ojo, A. I. (2014). Gender and job satisfaction: A study of library staff in private University libraries in Ogun State, Nigeria. Journal of New Media and Mass Communication. http://www.pakinsight.com/pdf-files/soc/91/JNMMC-2014-1(1)-12-19.pdf

Serban, Andreea, and Luan, (2002). Infomap of types of library sources. A complete guide to discovering corporate information resources. Englewood Cliffs, NJ: Prentice Hall.

Spector, P. E. (2011). Job satisfaction: Application, assessment, causes and consequences. Thousand Oaks, CA: SAGE.

Suliman, A. and Al-Hosani, A. A. (2014). Job satisfaction and knowledge sharing: The case of the UAE Issues in Business Management and Economics 2 (2): 024-033 